\title{
Reviews
}

\section{Postharvest Handling of Heliconia, Red Ginger, and Bird-of-Paradise}

\author{
Teeranuch Jaroenkit ${ }^{1}$ and \\ Robert E. Paull ${ }^{2}$
}

\begin{abstract}
AdDitional INDEX WORDS. postharvest handling, water loss, chemical treatments, senescence, abscission, vase life
\end{abstract}

Summary. Heliconia (Heliconia spp.), red ginger (Alpinia purpurata), and bird-of-paradise (Strelitzia reginae) inflorescences have similar stem structures and postharvest handling regimes. Inflorescences, especially heliconia, should be harvested in the morning while still turgid, and at the most suitable stage of development which varies with the species, its proposed use, and market requirements. Treatments that extend postharvest vase life, either or both enhance water uptake or prevent water loss and provide an exogenous energy source. Use of the most suitable temperature for shipping and storage prolongs vase life. Heliconia should be shipped and stored at $>10$

University of Hawaii at Manoa, College of Tropical Agriculture and Human Resources journal series 4633 This work was partially supported by USDA-CSREES Special Grants 96-34199-2645

${ }^{1}$ Lecturer, Department of Horticulture, Maejo University, Sansai, Chiang Mai 50290, Thailand.

${ }^{2}$ Professor, Department of Tropical Plant and Soil Sciences, University of Hawaii at Manoa, 3190 Maile Way, Honolulu, HI 96822; e-mail paull@hawaii.edu.

Hor'technology • April-June $2003 \quad$ 13(2)
${ }^{\circ} \mathrm{C}\left(50.0{ }^{\circ} \mathrm{F}\right)$, red ginger $>12{ }^{\circ} \mathrm{C}(53.6$

$\left.{ }^{\circ} \mathrm{F}\right)$, and bird-of-paradise at $>8{ }^{\circ} \mathrm{C}$ $\left(46.4^{\circ} \mathrm{F}\right)$. Sucrose $(10 \% \mathrm{w} / \mathrm{v})$, citric acid $\left[150 \mathrm{mg} \cdot \mathrm{L}^{-1}(\mathrm{ppm})\right]$ and 8 hydroxyquinoline citrate $\left(250 \mathrm{mg} \cdot \mathrm{L}^{-1}\right)$ are major chemicals used in pulsing and holding solution for bird-ofparadise. Holding solutions for red ginger are similar except $2 \%(\mathrm{w} / \mathrm{v})$ sucrose is recommended. The response of heliconia inflorescences to different pulsing and holding solutions has been shown to be negligible. A 200 $\mathrm{mg} \cdot \mathrm{L}^{-1}$ benzyladenine spray extends the vase life of red ginger and heliconia. Hot water treatment of red ginger at $49^{\circ} \mathrm{C}\left(120.2^{\circ} \mathrm{F}\right)$ and $50{ }^{\circ} \mathrm{C}$ $\left(122.0^{\circ} \mathrm{F}\right)$ for 12 to $15 \mathrm{~min}$ extends postharvest vase life, kills most of the pests that infest red ginger, and reduces the geotropic response. The major postharvest problems are saprophytic mold on bird-of-paradise, negative geotropic response of red ginger, and insect infestation of all three flowers. There is no reported method to control the postharvest nectar and slime production on birdof-paradise that provides a substrate for saprophytic mold growth. Dipping inflorescences in benomyl or thiobendazole (TBZ) at $200 \mathrm{mg} \cdot \mathrm{L}^{-1}$ does help control postharvest mold growth in bird-of-paradise and heliconia. Compared to most temperate flowers, there is a need for greater understanding of morphological and physiological factors that limit the vase life of heliconia, red ginger and bird-of-paradise flowers.

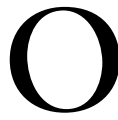

ptimum postharvest handling is essential to maintain the quality and prolong the vase life of cut flowers, including tropical cut flowers. Information about handling of other cut flowers, such as rose, carnation, and orchids, are abundant compared to that about tropical flowers. A heliconia bibliography published by the Heliconia Society International (Barnes, 1992), contains 1344 citations beginning in the year 1645 to the present, but only 23 deal with postharvest handling. The inflorescences of ginger, and bird-of-paradise have received even less attention. The most recent review of postharvest handling for tropical cut flowers was published in 1993 (Criley and Paull, 1993). The objectives of this review, therefore, are to collect all available published and some unpublished data and update the status on the postharvest handling of heliconia, red ginger and bird-of-paradise. Due to the similarities of the handling systems and postharvest problems for these tropical cut flowers, it is difficult to review information for each commodity without redundancy. To avoid this problem, the available information is reviewed by first describing senescence symptoms and the factors associated with their postharvest vase life.

\section{Postharvest vase life and senescence symptoms}

Heliconia. Senescence symptoms of heliconia inflorescences (Fig. 1) include darkening of the bract base, drying of bract tips (Paull, 1991) and stem bending (Whittaker, 1993). In psittacorum types (Heliconia psittacorum), necrosis of the bract tip

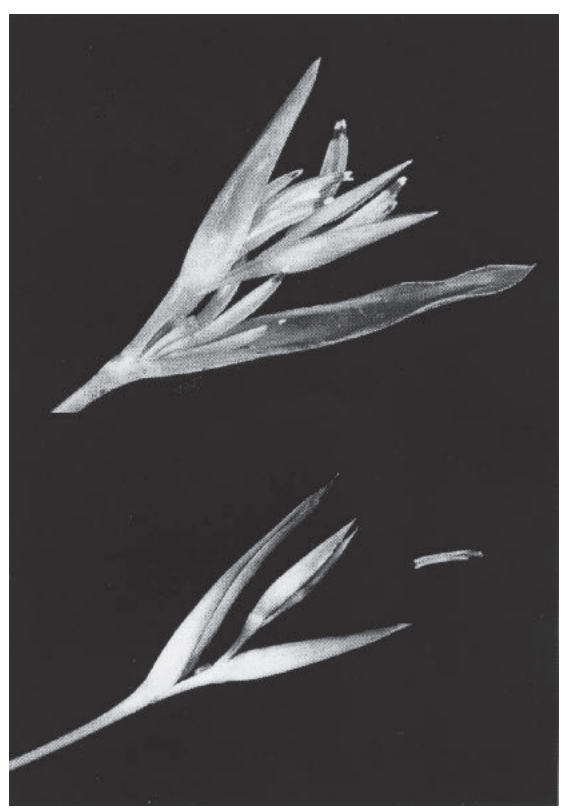

Fig. 1. Heliconia senescence symptoms include abscission of the true florets within a day of harvest followed by bract darkening and bract tip drying. Upper inflorescence is from the day of harvest, the bottom is at the end of vase life. 


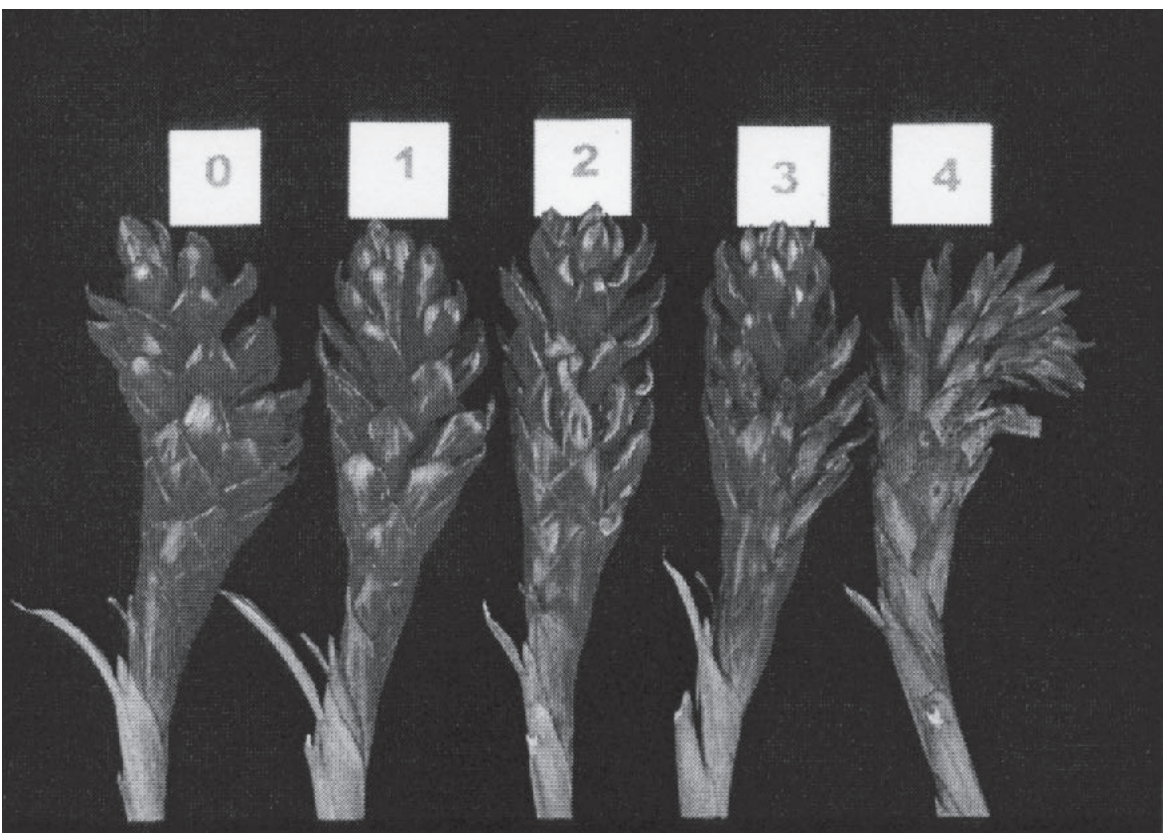

Fig. 2. Stages of red ginger inflorescence senescence symptoms include bract discoloration and bract drooping.

greater than $1.5 \mathrm{~cm}(0.59$ inch $)$ is considered to be the end of marketable vase life (Ka-ipo etal., 1989). The true flower usually lasts but $1 \mathrm{~d}$ before abscising, so bract appearance is the concern in assessing postharvest life.

Heliconia shows considerable genetic differences in vase life (Criley, 1990; Criley and Broschat, 1992; Powell, 1991) and is used as a major criteria to select promising lines (Powell, 1991). One week is the maximum vase life for large heliconias such as 'Sexy Pink' (H. chartacea) (Criley, 1990), while $H$. caribaea and $H$. wagneriana vase lives are reported to be $15 \mathrm{~d}$ or longer (Criley, 1990; Powell, 1991). $H$. orthotrichavase life can range from 19 to 26 d (Yamakawa et al., 1999).

For the small heliconias, the vase life varies with cultivar, stage of flower development, and time of day when harvested. The postharvest vase life of the better selections of the psittacorum types ranges from 14 and $17 \mathrm{~d}$ (Broschat and Donselman, 1983a; Broschat et al., 1984; Criley and Broschat, 1992). The vase life for 'Fireflash' (Powell, 1989) was from 4 to $7 \mathrm{~d}$ and up to $24 \mathrm{~d}$ for 'Golden Torch', 'Andromeda', and 'St. Vincent Red' (Broschat et al., 1984; Donselman and Broschat, 1986).

RED GINGER. Red ginger inflorescence senescence (Fig. 2) is marked by discoloration in the center of the bract, drooping of the bract tip away from the central axis (Chantrachit and Paull, 1998), and inrolling of the leaves (Paull,
1991). These symptoms are thought to be associated with water loss and a reduction in water uptake (Paull, 1991), due possibly to physiological plugging of the water-conducting tissue, as intact plant show rapid overnight rehydration of the inflorescence after water stress.

The postharvest vase life of the most common commercial variety, varies from $5 \mathrm{~d}$ in young flowers with a small $[<1 \mathrm{~cm}(0.4$ inch $)]$ stem diameter (Broschat and Donselman, 1988) to $25.5 \mathrm{~d}$ for the standard size flower (Hara et al., 1997). The end of vase life occurs when $20 \%$ to $30 \%$ of total bracts show browning, when the bract tip bends away from the axis $>90^{\circ}$ (Chantrachit and Paull, 1998), or when the inflorescence and stem have lost $10 \%$ of their fresh weight (Tjia, 1988).

BIRD-of-PARAdise. Senescence symptoms include floret desiccation and bract darkening (Fig. 3). Vase life is terminated when the last floret has withered (Halevy et al., 1978), the bract base darkens, and when the leaves curl (Paull, 1991). The cause is probably a rapid decline in water uptake, associated with possible blockage of the stem vascular tissue (Paull, 1991) or bract senescence.

Reported bird-of-paradise vase life varies considerably from 6 to $8 \mathrm{~d}$ (Halevy et al., 1978) to $15.5 \mathrm{~d}$ (El-Saka et al., 1995). This difference may reflect in part the different criteria used for evaluation of inflorescence vase life, as suggested for the large differences in vase life reported for heliconia (Criley, 1995). El-Saka et al. (1995) did not give the criteria used to evaluate inflorescence vase life. When properly handled, inflorescences can last for about $14 \mathrm{~d}$ (Halevy et al., 1978; Sacalis, 1993). Stem length is not a major factor contributing to this range since both studies used similar stem lengths of 80 and $90 \mathrm{~cm},(31.5$ and 35.4 inches), respectively. When stem lengths of 35 and $70 \mathrm{~cm}$ (13.8 to 27.6 inches) are compared (Chantrachit and Paull, 1998), no significant difference in vase life ( 14 to $16 \mathrm{~d}$ ) is found between younger or mature inflorescences. Inflorescences harvested in the cool season tend to have a slightly longer vase life than warm season inflorescence (Chantrachit and Paull, 1998). No varietal differences have been reported.

\section{Preharvest factors}

The effects of preharvest factors on inflorescence production and plant growth and development have been reported elsewhere (Criley, 1985; Criley, 1989; Criley and Halevy, 1985). In most cases, the effect on inflorescence quality and vase life were not evaluated. Growth and flower production of psittacorum types are greatly affected by lightintensity (Broschat and Donselman, 1983a, 1983b), though inflorescence quality and postharvest vase life are not significantly affected (Broschat and Donselman, 1983a). However, the shortest vase life of heliconia flowers grown in Denmark and held in tap water was 2 weeks when harvested during the winter compared to 4 weeks during the summer (Bredmose, 1987). Temperature has a greater effect on flower production than inflorescence quality and postharvest vase life. Inflo-

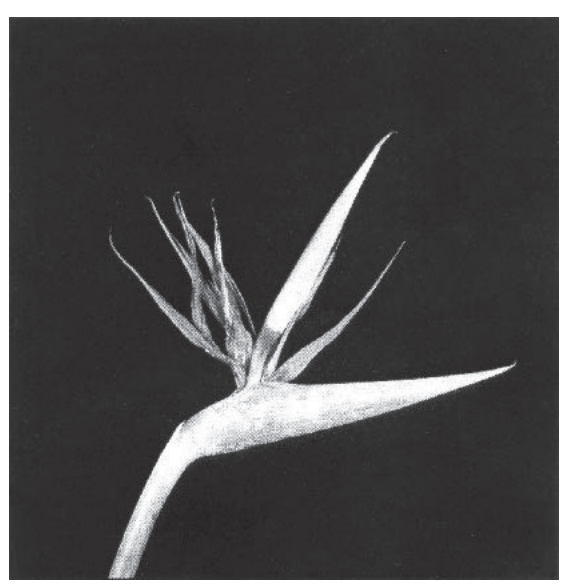

Fig. 3. Bird-of-paradise senescence include floret and bract darkening. 
rescence production of psittacorum types is reduced at air temperature below $10^{\circ}$ to $12.5^{\circ} \mathrm{C}\left(50.0\right.$ to $\left.54.5{ }^{\circ} \mathrm{F}\right)$ (Broschat and Donselman, 1987).

Potassium fertilization from 0 to $600 \mathrm{~g} \cdot \mathrm{m}^{-2}\left(17.7 \mathrm{oz} / \mathrm{yard}^{2}\right)$ per year did not significantly affect psittacorum inflorescence quality. If nitrogen fertilizer rate is increased from 142 to $568 \mathrm{~g} \cdot \mathrm{m}^{-2}$ (4.2 to $16.7 \mathrm{oz} / \mathrm{yard}^{2}$ ) of nitrogen per year from Osmocote 17N-1.3P-8.3K (Scotts Consumer Service, Marysville, Ohio) the number of saleable red ginger inflorescence increases nearly $70 \%$, without affecting postharvest vase life (Broschat and Donselman, 1988).

\section{Harvesting and handling system}

Stage of deVelopment AND HARVESTING TIME. Heliconia and red ginger are harvested by cutting rather than by pulling the inflorescence from the plant clump, as recommended for bird-ofparadise (Sacalis, 1993). The stage of inflorescence development at harvest varies depending on its use. Generally, heliconia inflorescences do not continue to open once cut (Broschat and Donselman, 1983a), therefore, they must be harvested at the stage at which they are to be marketed. Psittacorum inflorescences can be cut at the tight flower stage or when one to three bracts are open (Criley, 1995; Donselman and Broschat, 1986), those harvested at a younger stage (no open bract) last $42 \%$ longer than those harvested at a mature stage (three to four bracts open) (Tjia and Sheehan, 1984). The common practice for Hawaiian growers is to harvest heliconia by cutting the inflorescence stalks near the soil line in the early morning (Criley, 1995; Criley and Paull, 1993). Although Broschat and Donselman (1983b) found that pulling out of the entire pseudostem of psittacorum types worked equally well. Harvesting time is crucial, psittacorum types harvested in the morning (0800 HR) had nearly $30 \%$ greater vase life than when harvested in the afternoon (1300 HR) (Broschat and Donselman, 1987). The longer vase life of morning harvested inflorescences is possibly associated with higher hydration status compared to the inflorescences water status in the afternoon.

During harvest, the foliage is stripped to one to three leaves attached to the stem of small heliconia, whereas the petioles are cut just above the top of the large heliconia inflorescence to pre- vent mechanical injury during transportation (Criley, 1996; Criley and Broschat, 1992). The stem of the small heliconias, such as the psittacorum types, are trimmed to $60 \mathrm{~cm}$ (23.6 inches) to $90 \mathrm{~cm}$, whereas those of large heliconias are $150 \mathrm{~cm}$ (59.1 inches) (Criley and Paull, 1993). The number of leaves attached to stem and stem length do not seem to affect postharvest vase life of heliconia (Ka-ipo et al., 1989). The leaf sheath is retained to provide additional mechanical support to the less mature lower stem.

Red ginger inflorescences are normally cut when they are about twothirds to three-fourths open with two to three leaves attached to the stem (Broschat and Donselman, 1988; Criley, 1996). There is no recommendation for time of harvest, but the general practice is to harvest the flowers in the morning when the stem lengths are from 60 to $150 \mathrm{~cm}$ (Criley and Paull, 1993). Among the tropical cut inflorescences reported in this review, red ginger is the only inflorescence when it has been recommended (Broschat and Donselman, 1988) to harvest it with the stem length as long as practical, since the stem length has a significant effect on prolonging postharvest vase life. The vase life increases two to three fold when the stem length is increased from $50 \mathrm{~cm}$ (19.7 inches) to $150 \mathrm{~cm}$, whereas stem diameter does not significantly affect postharvest vase life (Broschat and Donselman, 1988). Although the number of leaves attached to the stem was thought to be one factor shortening flower vase life (Rietow, 1986), a recent study has shown that the leaves do not affect inflorescence vase life (Chantrachit, 1999). The vase life of the attached leaf and inflorescence may be independent; the attached leaf shows inrolling symptom several days before the inflorescence starts to senesce (Tjia, 1988). Because of the leaf inrolling, the recommendation is to remove the leaves before packing red ginger (Akamine, 1976; Rietow, 1986).

A few days before harvest, the birdof-paradise inflorescences are normally covered by a paper or wax paper bag, wrapped with electrical tape, a wide elastic band or a plastic net sleeve installed to prevent inflorescences from opening during transportation, and hence reduce mechanical injury (Criley and Paull, 1993; Tanouye, 1986). Inflorescences are normally harvested in the morning by pulling the stem from the plant clump at the mature stage, characterized by the bract being split at the top, allowing the orange sepals inside the inflorescence boat to be seen (Criley and Paull, 1993). Generally, no leaves are left attached to the stem. Inflorescences may be harvested a few days earlier than the commercial stage if a sugar pulsing treatment is used to enhance flower bud opening (Halevy et al., 1978). Unlike heliconia and red ginger, that are held in water from field to the packing plant, bird-of-paradise flowers are often collected and transported dry to the packing plant (Criley and Paull, 1993). This practice may negatively affect vase life.

Cleaning and grading system. Grades and standards vary with production area and number have been described (Criley and Paull, 1993; Delima, 1986; Tjia and Broschat, 1987), often informal grades are set up among the shippers, wholesalers and retailers. Tropical cut flowers exported to many subtropical and temperate markets have to be cleaned of field dust or disinfested of insects. Insect disinfestation steps impose additional cleaning steps and treatments. Insect infestations are more serious with red ginger and heliconia than for bird-of-paradise, because their flower structure provides numerous hiding sites between the bracts to shield insects. The common Hawaii practice is to handwash using insecticidal soap or a dip (Hansen et al., 1990). Washing the flowers in a detergent solution and then rinsing with water from a pressurized nozzle (Criley and Paull, 1993) has been suggested to also remove field heat, though the additional mechanical injury may outweigh any advantage (Nowak and Rudnicki, 1990). Newer approaches for insect disinfestation involve hot water dips at $45^{\circ} \mathrm{C}\left(113.0^{\circ} \mathrm{F}\right)$ to $50{ }^{\circ} \mathrm{C}$ for up to $15 \mathrm{~min}$ and fumigation (Chen and Paull, 1998; Hara et al., 1993, 1996, 1997). Hot-water-dipped inflorescences, after being allowed to dry while standing in the water, are graded and packed into cartons.

During shipping, bird-of-paradise can suffer from the growth of saprophytic mold on the stem and inflorescence; a fungicide treatment (benomyl, thiabendazole) is recommended, before packing (Halevy et al., 1978). After harvest, bird-of-paradise is trimmed to a stem length of 60 to $120 \mathrm{~cm}(47.2$ inches) before the application of the fungicide (Criley and Paull, 1993).

PACKING, SHIPPING AND STORAGE 
TEMPERATURE. It is common practice to mix-pack different tropical cut flowers in the same carton. Small heliconias are bunched into 10 inflorescences, with or without a plastic sleeve (Criley and Paull, 1993), whereas the large heliconia inflorescences are wrapped with paper to prevent damage during transportation. Red ginger is also bunched, but with fewer inflorescences per bunch. In Thailand, harvested red ginger stems and inflorescence are placed in tap water for washing and removing the field heat before trimming to the desired length and shipped to the market standing in a bucket of water (Yotpanya, 1995). Birdof-paradise can be packed individually or bunched into five inflorescences (Criley and Paull, 1993). If inflorescences are not wrapped, bagged, or no plastic or mesh sleeve was installed in the field, the recommendation is to wrap the boat to prevent the florets from opening during transportation (Whittaker, 1993).

Tropical cut flowers are packed into cardboard cartons with a plastic film liner, the layers of flowers separated by newspaper, and the individual inflorescences secured with moist shredded newspaper between the layers. Bird-ofparadise is packed dry with shredded newspaper (Akamine, 1976), as moistened paper enhances the development of mold on the bracts during shipping (Tanouye, 1986). Saprophytic mold growth is thought to occur on the nectar that can contain $128 \mathrm{mg} \cdot \mathrm{g}^{-1}(128,000$ ppm) total sugar (Kronestedt et al., 1989). It is advisable to assure that the flower is dry after the fungicide treatment and without excess nectar, before packing. There is also a mucilage secreted during floret opening from the base of the bract that could also provide substrate for mold growth.

Storage temperatures for tropical cut flowers vary as bird-of-paradise is less cold sensitive than heliconia and ginger. The minimum recommended storage temperature for bird-of-paradise is $>8{ }^{\circ} \mathrm{C}$ (Halevy et al., 1978; Kofranek, 1982), >10 ${ }^{\circ} \mathrm{C}$ for heliconia (Broschat and Donselman, 1983b), and $>12{ }^{\circ} \mathrm{C}$ for red ginger (Broschat and Donselman, 1988). To maintain good quality, relative humidity should be greater than 90\% (Paull, 1991).

Chilling injury (CI) symptoms in heliconia, that include bract and flower darkening, can occur at $10{ }^{\circ} \mathrm{C}$ in less than $2 \mathrm{~d}$ (Paull, 1991), whereas bird-ofparadise can be stored at $5^{\circ} \mathrm{C}\left(41.0^{\circ} \mathrm{F}\right)$ for up to $7 \mathrm{~d}$ and show no CI symptoms (Halevy et al., 1978).

Temperature extremes are experienced during shipping of tropicals to market in temperate climates (Paull, 1987). The greatest problem occurs in winter when cartons are exposed to freezing temperature after arrival at the destination, and during ground shipment to wholesalers and retailers. Mishandling by cargo employees can be an occasional problem when warning labels such as "Perishable Cut Flowers" are ignored. Labeling is highly recommended on the cardboard box such as suggested for air freight shipments of heliconia rhizomes (Heliconia Society International, 1989), and additional training at various steps in the handling chain can minimize this loss. Occasionally losses due to overheating are experienced in summer when shipping containers are left exposed to the sun on the airport tarmac.

Gravity influences red ginger inflorescence quality by causing tip curvature, similar to that of gladiolus and snap dragon. Red ginger flower stalks should be held vertically to avoid negative geotropism (Broschat and Donselman, 1988; Criley and Paull, 1993), although this recommendation is often not practical for commercial shipping and storage. A heat treatment (49 ${ }^{\circ} \mathrm{C}$ for $12 \mathrm{~min}$ ) before packing significantly reduces the geotropic response (Chantrachit, 1999; Hara et al., 1997).

\section{Postharvest physiology and technology}

Water status of cut stems. The water uptake rate of the psittacorum types 'Lady Di' and 'Sassy' declines after harvest (J.W. Dai and R.E. Paull, unpublished data). For 'Parakeet', the average water uptake rate is $3 \mathrm{~mL}(0.1 \mathrm{fl}$ $\mathrm{oz})$ per inflorescence with no leaves during the first $15 \mathrm{~d}$ after harvest. The greater the number of leaves left attached to the stem, the greater the water uptake rate (Ka-ipo et al., 1989). However, since there are no above ground vascular connections between the flower peduncle and the leaves (Criley and Broschat, 1992), the higher rate of water uptake when leaves are attached has no effect on flower vase life (Ka-ipo et al., 1989). A heliconia flower stem that has all the leaves and leaf sheaths removed has very low water uptake rates (Broschat and Donselman, 1983b; Criley and Broschat, 1992; Criley and
Paull, 1993; Powell, 1991), hence the flower gains little weight once cut (Tjia and Sheehan, 1984). Microorganisms in the vase solution do not seem to limit heliconia vase life since the antimicrobial agent 8-hydroxyquinoline citrate (HQC) (Marousky, 1971) in the vase solution does not extend vase life (Tjia and Sheehan, 1984).

The very low water uptake rate by cut heliconia may be due to the immaturity of the basal interculary meristem that is still growing (Ka-ipo et al., 1989). After harvest, the inflorescence peduncle will often protrude up to $1 \mathrm{~cm}$ from the end of the cut leaf sheath. It was hypothesized that cutting the stem above the intercalary meristem should improve water uptake as the stem near the flower is more mature than the stem near the basal end. However, the vase life of the psittacorum type. 'Parakeet' cut at different lengths failed to support this hypothesis (Ka-ipo et al., 1989).

The psittacorum inflorescence on the plant has a sap flow rate 2 -fold higher at night than during the day, suggesting that root hydrostatic pressure during the night may play a role in water movement to the inflorescence on the plant (R.E. Paull and J.W. Dai, unpublished data). However, attempts to supply water to the cut inflorescence using pressure to a cut stem were not successful. Changes in the postharvest water status of red ginger and bird-ofparadise stems have not been reported.

Pulsing treatments and holding SOLUTIONS. The very low water uptake rate of heliconia may explain why preservatives, alone or in combination with detergents, fail to extend vase life (Broschat and Donselman, 1983a; Broschat et al., 1984; Ka-ipo et al., 1989; Tjia, 1985; Tjia and Sheehan, 1984). Chemicals and detergents tested in pulsing treatments and holding solutions include 8-hydroxyquinoline sulfate (HQS) or citrate, sucrose, silver thiosulfate(STS), dithiothreitol(DTE), commercial preservative solution, citric acid, and benzyladenine (BA) (Bredmose, 1987; Broschat and Donselman, 1983b; Broschat et al., 1984; Ka-ipo et al., 1989; Whittaker, 1993).

Bird-of-paradise's vase life is increased by chemical pulsing treatments and holding solutions. The recommended solution for pulsing bird-ofparadise is $10 \%$ sucrose $+250 \mathrm{mg} \cdot \mathrm{L}^{-1} 8$ $\mathrm{HQC}+150 \mathrm{mg} \cdot \mathrm{L}^{-1}$ citric acid for $2 \mathrm{~d}$ at $22{ }^{\circ} \mathrm{C}\left(71.6^{\circ} \mathrm{F}\right)$ (Halevy et al., 1978). 
Other researchers recommend pulsing bird-of-paradise for only $\mathrm{l} \mathrm{d}$ with the same solution (Kofranek, 1982). Whittaker (1993) failed to show a benefit of a 46-h sugar-pulsing treatment applied a few days after harvest for birdof-paradise, though Halevy etal., (1978) reported that delaying treatment was still beneficial. The difference in response reported by Halevy et al., (1978) and Whittaker (1993) may be due to the differences in pulsing solutions used and the high variation in Whittaker's data. There is no additional increase in vase life if the sucrose concentration in the pulsing solution was raised from $10 \%$ to $25 \%$ (Halevy et al., 1978). Solutions used for pulsing show significant effects on floret opening when used as holding solutions, and the starting time of pulsing, before or after storage, does not affect the solution's ability to extend vase life (Halevy et al., 1978). Dipping bird-of-paradise stem in silver nitrate solution $\left(1,000 \mathrm{mg} \cdot \mathrm{L}^{-1}, 15 \mathrm{~min}\right)$ significantly reduces flower vase life, if the stems are not subsequently pulsed with sucrose solutions (Halevy et al., 1978). A recent report indicated that the best postharvest treatment for bird-of-paradise was a dip in STS for $10 \mathrm{~min}$, pulse in $25 \mathrm{mg} \cdot \mathrm{L}^{-1}$ gibberellic acid overnight, and then held in a vase solution containing $10 \%$ sucrose $+200 \mathrm{mg} \cdot \mathrm{L}^{-1} 8$-HQS + $150 \mathrm{mg} \cdot \mathrm{L}^{-1}$ citric acid (El-Saka et al., 1995). This regime was reported to extend vase life from $15.5 \mathrm{~d}$ to $38.5 \mathrm{~d}$. However, it is not clear why the vase life of the control bird-of-paradise flowers (El-Saka et al., 1995) was nearly twice that of other reports (Criley and Paull, 1993; Halevy et al., 1978; Sacalis, 1993). Attempts to duplicate this report have been unsuccessful; part of the difference may lie in the criteria used to judge the end of vase life that are not given by ElSaka et al., (1995).

Chantrachit (1999) found a positive relationship between red ginger infloresence stem sugar content and vase life, while water balance was not as closely related to vase life. Pulsing red ginger with $2 \%$ sucrose $+800 \mathrm{mg} \cdot \mathrm{L}^{-1} 8$ HQC for $4 \mathrm{~h}$ (Broschat and Donselman, 1988 ) or pink ginger with $10 \%$ sucrose + $200 \mathrm{mg} \cdot \mathrm{L}^{-1} 8$-HQC for $3 \mathrm{~h}$ (Whittaker, 1993 ) did not extend red ginger vase life. Pulsing with $2 \mathrm{mM}$ STS for $4 \mathrm{~h}$ causes phytotoxicity, and reduces flower vase life by about one-third (Broschat and Donselman, 1988). A holding solution containing $2 \%$ sucrose +200 $\mathrm{mg} \cdot \mathrm{L}^{-1} 8$-HQ extended vase life about two fold (Broschat and Donselman, 1988; Tjia, 1988; Whittaker, 1993). When an acidifying agent such as citric acid or antiethylene compound aminooxyacetic acid (AOA) are added to the holding solution, the vase life of the flower increased nearly 3 -fold for citric acid and 2 -fold for AOA (Tjia, 1988). Although the function of acidifying agent is not known, part of its function is thought to be the control of bacterial growth in the vase solution (Marousky, 1971). Microorganisms in the vase solution seem to play a role in red ginger postharvest life as simply recutting the stem before placing into the vase water almost doubles vase life compared to flower stems that have not been recut (Broschat and Donselman, 1988). Possibly, the cut end of stems either serves as a major site for microbial growth (van Doorn et al., 1989), or recutting exposes open xylem for improved water intake.

ANTITRANSPIRANTS AND BENZYLADENINE DIPS. Minimizing the decline in water uptake after harvest and water loss by evaporation is crucial in extending heliconia vase life (Criley and Broschat, 1992). Several antitranspirants have been tested and some have extended the vase life of tropical cut flowers. Dipping of psittacorum 'Parakeet' in Wilt-Pruf(1:10 dilution; Wilt-PrufProducts, Inc., Essex, Conn.) or a wax ( $1: 4$ dilution) resulted in a $36 \%$ increase in vase life (Ka-ipo et al., 1989). Similar result (26\% increase in vase life) were reported for heliconia 'Nickeriensis' after dipping the inflorescence in Folicote ( $1: 40$ dilution; Puteaux SA, Les Clayes Sous Bois, France) (Whittaker, 1993). However, researchers in Florida (Broschat and Donselman, 1987) and Hawaii (R. E. Paull, unpublished data) found only small increases in heliconia vase life after dipping in a number of antitranspirants. The limited responses may be due to a failure to completely coat the bract surface. The waxy surface of the bract cuticle and the ridged nature of the surface with stomata located in the grooves may impede complete coverage (Criley and Paull, 1993). Ginger also does not respond to antitranspirant dips of Folicote (1:50 and 1:3) or Vapor Gard (1:40; Miller Chemical and Fertilizer Corp., Hanover, Pa.) (Broschat and Donselman, 1988) and pink ginger to Folicote (1:40) (Whittaker, 1993).

Benzyladenine has been used in Hawaii as a postharvest treatment to prolong postharvest vase life, especially for anthurium (Paull and Chantrachit, 2001). Benzyladenine $\left(200 \mathrm{mg} \cdot \mathrm{L}^{-1}\right)$ as a dip or spray treatment, increases the vase life of pink ginger for about $10 \mathrm{~d}$ (Whittaker et al., 1992) and for about 8 $\mathrm{d}$ of the heliconia 'Nickeriensis' (Whittaker, 1993). Bird-of-paradise has not shown a positive response to antitranspirant or BA dip treatment (Paull and Chantrachit, 2001). This is not surprising, as the aesthetic value of the bird-of-paradise depends on its true floral parts (sepals and petals), which are delicate and easily damaged (Criley and Halevy, 1985). These delicate floral parts compared to the more robust modified leaf flower bracts of heliconia and red ginger inflorescence (Criley, 1985; Powell, 1991).

Hot WATER TREATMEnt. Recent studies(Chantrachit and Paull, 1998; Hansen et al., 1991a; Hara et al., 1996, 1997) have shown that hot water treatment can extend the vase life of tropical cut flowers, especially red ginger. Originally, this treatment was studied as a postharvest insect disinfestation treatment for tropical cut flowers in Hawaii (Hansen et al., 1991a; Hara et al., 1993, 1996; Tenbrink et al., 1994) and the ability to extend flower vase life was a reported side effect (Hara et al., 1993). Water temperatures for insecticidal activity were $40{ }^{\circ} \mathrm{C}\left(104.0{ }^{\circ} \mathrm{F}\right)$ to $50{ }^{\circ} \mathrm{C}$ (Tenbrink et al., 1994), and overlap with 49 to $50{ }^{\circ} \mathrm{C}$ that extend vase life, depending on exposure times (Chantrachit and Paull, 1998). The ability of the hot water treatment to extend flower vase life is not consistent, but varies with season of harvest (Hara etal., 1996), variety (Chantrachit, 1999), and is less effective during high rainfall periods and in the cool season (Chantrachit and Paull, 1998). In Hawaii, a hot water treatment at $49^{\circ} \mathrm{C}$ for 12 min sometimes increases vase life of $H$. chartacea 'Sexy Pink', $H$. caribaea (red) and H. psittacorum (red) (A. H. Hara, unpublished data). No details are available as to damage thresholds for temperature and duration of exposure for different heliconia species.

\section{Postharvest problems}

INSECT DISINFESTATION. Most tropical cut flowers and foliage, and other commodities, must be inspected to be certified free of live insect infestation before shipment (Hara et al., 1991), otherwise they can be rejected for shipment. Alternatively, the shipments are inspected upon arrival at their destina- 
tion and can be denied entry or be required to be fumigated.

Banana aphids (Pentalonia nigronervosa), mealybugs (Planocaccus affinis, Pseudococcus spp.), green scale (Coccus viridis), and cardamon thrips (Sciothrips cardamomi) are frequently found on heliconia and ginger flowers in Hawaii (Hansen et al., 1991b; Hara et al., 1993). Disinfestation treatments for cut flowers that are approved by the United States Department of Agriculture-Animal Plant Health Inspection Service (APHIS) are limited to hand removal, chemical dips, and methyl bromide fumigation (Hansen and Hara, 1994). Hand removal and chemical dips are time and labor intensive, while fumigation requires a secure and complex facility, and well-trained personnel. The fumigant methyl bromide has a waste disposal problem associated with environmental pollution (United Nations Environmental Program, 1992), besides frequently causing phytotoxicity. Methyl bromide is to be withdrawn by 2010 (United Nations Environmental Program, 1992). Most insects are killed by hydrogen cyanide at $2500 \mathrm{mg} \cdot \mathrm{L}^{-1}$ on ginger flowers (Hansen et al., 199lb), or on heliconia at $2.8 \mathrm{~g} \cdot \mathrm{m}^{-3}(0.0028$ $\mathrm{oz} / \mathrm{ft}^{3}$ ) for $30 \mathrm{~min}$ (Hara, 1994). However, this treatment lacks U.S. Environmental Protection Agency registration as an insect fumigant (Hansen et al., 1991b). Therefore, alternative disinfestation methods for postharvest quarantine treatments are being sought.

A systems approach consisting of a preharvest insecticide application and a postharvest insecticidal dip and inspection was developed by Hata et al. (1994). This system provides quarantine security that eliminates all insects on red ginger. A dip solution of 1.6 $\mathrm{g} \cdot \mathrm{L}^{-1}(160,000 \mathrm{ppm})$ diazinon (50WP; Drexel Chemical Co., Memphis, Tenn) plus $1.8 \mathrm{~mL} \cdot \mathrm{L}^{-1}(180,000 \mathrm{ppm})$ of a light oil and malathion (57EC; Platte Chemical Co., Greeley, Colo.) at 1 $\mathrm{mL} \cdot \mathrm{L}^{-1}(100,000 \mathrm{ppm})$ for $5 \mathrm{~min}$ (Tenbrink et al., 1991a) are used, while others (Hansen et al., 1991b) have found that tau-fluvalinate (Mavrik; Wellmark International, Schaumburg, Ill.) and cyfluthrin (Tempo-2; Bayer Corp., Kansas City, Mo.) are highly effective against the banana aphid but less effective against mealybugs. Trials showed that tau-fluvalinate + Safer insecticidal soap (Woodstream Corp.,
Lititz, Pa.) was the best of the combination dips for psittacorum 'Rhizomatosa' and ginger flowers (Tenbrink et al., 199la, 1991b).

Because hand removal of insects is tedious and subject to missing insects, physical disinfestation treatments that show the most promise are heat treatments using vapor heat and hot water. The vapor heat treatment $[46.6$ ${ }^{\circ} \mathrm{C}\left(116^{\circ} \mathrm{F}\right)$ at $90 \%$ to $98 \%$ relative humidity (RH) for l h] killed 90\% to $100 \%$ of nymphs and adults of banana aphid, green scale, cockerell scale (Planococcus. cockrelli), and mealybugs (Nipaecoccus nipae, Planococcus citri, Planococcus affinis, and Planococcus longispinas) without damage to most heliconias (Hansen et al., 1992). However, vapor heat treatment facilities are expensive compared to insecticidal dips (Hara, 1994). A hot water dip of 12 min at $49^{\circ} \mathrm{C}$ is effective against most pests on red ginger (Hara et al., 1997, 1996). To prevent damage during the hot water treatment, Hara et al. (1996; 1997) induced thermotolerance by conditioning flowers with hot air $(40$ ${ }^{\circ} \mathrm{C}$ at $64 \% \mathrm{RH}$ for $2 \mathrm{~h}$ ) before subjecting the flowers to the hot water treatment. Hot water at $49^{\circ} \mathrm{C}$ for $10 \mathrm{~min}$ is effective against the magnolia white scale (Pseudaulacaspis cockerelli) without reducing the vase life of bird-ofparadise leaves (Hara et al., 1993). Irrespective of the treatment used, a final inspection of flowers for live insects is needed to ensure pest-free status.

Disease prevention. Birds-ofparadise sometimes develop saprophytic molds on the flowers during shipping and storage (Tanouye, 1986). Botrytis (Botrytis cinerea) has been identified as a cause of floret browning and bract lesions (Halevy et al., 1978). Dipping flowers in 200 $\mathrm{mg} \cdot \mathrm{L}^{-1}$ benomyl or TBZ is recommended (Halevy et al., 1978; Criley and Paull, 1993). This treatment is also recommended as postharvest treatment to control saprophytic mold on heliconia (Paull, 1991). These molds may reflect a carry over of spores to postharvest storage stage from the field treatments used to control diseases and nematode (Criley, 1996). Postharvest disease in ginger is not documented.

Chilling injury. Low temperatures during shipping or storage are a well known method to maintain flower quality (Halevy and Mayak, 1981).
However, tropical cut flowers, unlike temperate cut flowers, are easily damaged when stored or shipped at temperature below 8 to $12^{\circ} \mathrm{C}$. Bird-ofparadise is less sensitive to low temperature than heliconia and red ginger. For example, heliconia bracts darkened after storage at $10^{\circ} \mathrm{C}$ in less than $2 \mathrm{~d}$ (Paull, 1991), while bird-of-paradise can be stored (bunches of five, wrapped with newspaper, and placed in fiberboard box lined with polyethylene sheet) for up to $7 \mathrm{~d}$ at $5{ }^{\circ} \mathrm{C}$ or 28 $\mathrm{d}$ at $8^{\circ} \mathrm{C}$ without losing their aesthetic value (Halevy et al., 1978). However, before packing bird-of-paradise in such conditions, flowers should be pulsed with $10 \%$ sucrose $+250 \mathrm{mg} \cdot \mathrm{L}^{-1} 8$ $\mathrm{HQC}+150 \mathrm{mg} \cdot \mathrm{L}^{-1}$ citric acid for $48 \mathrm{~h}$ at $22{ }^{\circ} \mathrm{C}$ to maintain flower quality after unpacking (Halevy et al., 1978).

GeOtropic ResPonse. Red ginger inflorescences show a strong negative geotropic response (Broschat and Donselman, 1988; Criley and Paull, 1993). Therefore, vertical storage and shipping is highly recommended (Broschat and Donselman, 1988, Criley and Paull, 1993; Paull, 1991). A hot water dip $\left(49^{\circ} \mathrm{C}\right.$ for $\left.12 \mathrm{~min}\right)$ significantly reduces the geotropic response of the red ginger inflorescence (Hara et al., 1997), from $92^{\circ}$ among control flowers to $17^{\circ}$ in the hot water treated-flowers. Geotropic responsiveness returns in about $7 \mathrm{~d}$ following the hot water treatment (Chantrachit, 1999). The mechanism of hot water inhibition of the geotropic response is unknown. Dipping red ginger inflorescence, with and without bracts, in tri-iodobenzoic acid (TIBA), an auxin movement inhibitor, similarly controls geotropic curvature (Chantrachit, 1999), suggesting that auxin movement may be inhibited in the hot water response.

Nectar ANd SLIME PROduction. The nectar produced by the flowers and the slime produced at the flower base of bird-of-paradise can reduce aesthetic appeal. The nectar production [ 1 to 2 $\mathrm{mL}(0.03$ to $0.07 \mathrm{fl} \mathrm{oz})$ per flower $]$ has $11.5 \%$ to $13 \%$ total soluble solids, while the slime has a total soluble solids of about $3 \%$. Slime production is greater during the cool season than in warm season flowers (T. Chantrachit and R. E. Paull, unpublished). The nectaries of bird-of-paradise are found in the carpel fusion zones of the ovary (Kronestedt et al., 1989) and secretion by the intact flower can occur for 
up to $7 \mathrm{~d}$ (Kronestedt and Robards, 1987). Nectar and slime production is undesirable to shippers, because it reduces the aesthetic value of the flower or may lead to microbial growth (Paull, 1991). Preventing mold growth on bird-of-paradise can be achieved by ensuring the inflorescence is dry and without nectar before packing (Paull, 1991) or dipping or spraying flowers with $200 \mathrm{mg} \cdot \mathrm{L}^{-1}$ benomyl or TBZ (Halevy et al., 1978). There is no reported method to control or prevent postharvest nectar and slime production in bird-of-paradise. In our studies, flowers harvested at a younger stage ( $2 \mathrm{~d}$ before commercial stage) have about one-third the nectar and slime production compared to later stages (commercial stage or $2 \mathrm{~d}$ after the commercial stage). However, aesthetic value of the younger flowers is less than that of older flowers, as bract color does not fully develop. This may be overcome if the young flowers are pulsed with a sugar solution, as recommended by Halevy et al. (1978).

\section{Conclusion}

Postharvest quality of tropical cut flowers depends on both preharvest and postharvest factors. Preharvest factors include environmental factors such as rainfall and temperature, cultivar, fertilizer levels, stage of flower development at harvest and time of day when harvested, whereas postharvest factors include all steps in the handling system until the flowers reaches the consumer.

The preharvest factors that affects postharvest vase life is the stage of flower development at harvest and the time of day when harvested. These may reflect the energy resources and water status of the cut flowers or inflorescences. Heliconia should be harvested at the one to three open bract stage, red ginger at two-third open florets and bird-of-paradise when the first orange color is visible but the florets have not opened. Most flowers should be cut in the morning when still turgid. Heliconias cut in the afternoon have a shortened vase life.

After harvest, flowers need to be cleaned and graded, and insect disinfestation treatments applied before packing and shipping. Shippers or growers do not usually pulse flowers with a sucrose solution before shipping to extend the vase life. These postharvest pulse treatments can be done at the supermarket or florist shop level and is highly recommended for bird-of-paradise. Currently, antitranspirant do not seem to have commercial value. BA dips or sprays show promise to extend the vase life for heliconia and red ginger.

Postharvest hot water treatments extend vase life. This treatment requires simple equipment and is versatile and cheap. When a suitable temperature and exposure time are selected, it can be used as a quarantine treatment, and to extend flower vase life and control negative geotropism in red ginger. Hot water treatments are now being used commercially by shippers in Hawaii for insect disinfestation.

A major problem for most tropical cut flower is chilling injury. Recommended temperature varies with commodity, and may also vary with cultivars. Little is known about relationship between exposure time and temperature for most tropical cut flowers.

\section{Literature cited}

Akamine, E.K. 1976. Postharvest handling of tropical ornamental cut crops in Hawaii. HortScience 11:125-127.

Barnes, S. 1992. Heliconia (Heliconiaceae): A bibliography. Bul. Heliconia Soc. Intl.

Bredmose, N. 1987. Postharvest ability of some new cut flowers. Acta Hort. 205:187194.

Broschat, T.K. and H.M. Donselman. 1983a. Production and postharvest culture of Heliconia psittacorum flowers in South Florida. Proc. Fla. State Hort. Soc. 96:272-273.

Broschat, T.K. and H. Donselman. 1983b. Heliconias: a promising new cut flower crop. HortScience 18:2.

Broschat, T.K. and H. Donselman. 1988. Production and postharvest culture of red ginger in South Florida. Proc. Fla. State Hort. Soc. 101:326-327.

Broschat, T.K. and H.M. Donselman. 1987. Tropical cut flower research at the University of Florida's Ft. Lauderdale Research and Education Center. Bul. Heliconia Soc. Intl. 2:5-6.

Broschat, T.K., H.M. Donselman, and A.A. Will. 1984. 'Andromeda' and 'Golden Torch’ heliconias. HortScience 19:736737.

Chantrachit, T. 1999. Postharvest physiology of red ginger inflorescence (Alpinia purpurata Vieill K. Schm). PhD diss. Univ. Hawaii, Manoa.
Chantrachit, T. and R.E. Paull. 1998. Effect of hot water on red ginger (Alpinia purpurata) inflorescence vase life. Postharvest Biol. Technol. 14:77-86.

Chen, C.C. and R.E. Paull. 1998. Tolerance of tropical fruits and a flower to carbonyl sulfide fumigation. Postharvest Biol. Technol. 14:245-250.

Criley, R.A. 1985. Heliconia, p. 125-129. In: A.H. Halevy (ed.). Handbook of flowering. CRC Press, Boca Raton, Fla.

Criley, R.A. 1989. Development of Heliconia and Alpinia in Hawaii: Cultivar selection and culture. Acta Hort. 246:247-258.

Criley, R.A. 1990. Production of heliconia as cut flowers and their potential as new potted plants. Hort. Dig. (Hawaii) 92:1-6.

Criley, R.A. 1995. Culture profileHeliconia psittacorum. Bul. Heliconia Soc. Intl. 8:9-11.

Criley, R.A. 1996. Techniques of cultivation in the ornamental Zingiberaceae. Bul. Heliconia Soc. Intl. 8:7-11.

Criley, R.A. and T.K. Broschat. 1992. Heliconia: Botany and horticulture of a new floral crop. Hort. Rev. 14:1-55.

Criley, R.A. and A.H. Halevy. 1985. Strelitzia reginae, p. 396-402. In: A.H. Halevy (ed.). Handbook of flowering. CRS Press, Boca Raton, Fla.

Criley, R.A. and R.E. Paull. 1993. Review: Postharvest handling of bold tropical cut flowers Anthurium, Alpinia purpurata, Heliconia, and Strelitzia. Acta Hort. 337:201-211.

Delima, D. 1986. Grades and standards for cut flowers. Hort. Dig. (Hawaii) 80:6-7.

Donselman, H. and T.K. Broschat. 1986. Production of Heliconia psittacorum for cut flowers in south Florida. Bul. Heliconia Soc. Intl. 1:4-6 (abstr.).

El-Saka, M., A.E. Awad, B. Fahmy, and A.K. Dowh. 1995. Trials to improve the quality of Strelitzia reginae Ait. flowers after cutting, p. 480-485. In: A. Ah-Oubahao and M. El-Osmari (eds.). Postharvest physiology, pathology and technology for horticultural commodities: Recent advances. Inst. Agronomique et Veterianaire Hassan II, Agadir, Morocco.

Halevy, A.H., A.M. Kofranek, and S.T. Besemer. 1978. Postharvest handling methods for bird of paradise flowers (Strelitzia reginae Ait.). J. Amer. Soc. Hort. Sci. 103:165-169.

Halevy, A.H. and S. Mayak. 1981. Senescence and postharvest physiology of cut flowers. Part 2. Hort. Rev. 3:59-143.

Hansen, J.D. and A.H. Hara. 1994. A review of postharvest disinfestation of cut 
flowers and foliage with special reference to tropicals. Postharvest Biol. Technol. 4:193212.

Hansen, J.D.,A.H. Hara, and V.L. Tenbrink. 1991a. Recent progress in the control of insect pests on tropical floral commodities, p. 54-60. In: Proceedings: The Hawaii Tropical Cut Flower Industry Conference. HITAHR, Univ. Hawaii Res. Ext. Serv. \#134.

Hansen, J.D., J. Chan, A.H. Hara, and V.L. Tenbrink. 1991b. Phytotoxic reaction of Hawaiian cut flowers and foliage to hydrogen cyanide fumigation. HortScience 26:53-56.

Hansen, J.D., A.H. Hara, and V.L. Tenbrink. 1992. Vapor heat: A potential treatment to disinfest tropical cut flowers and foliage. HortScience 27:139-143.

Hansen, J.D., E. Tanouye, and R. Peckenpaugh. 1990. Flower cleaning and handling for export shipment. Bul. Heliconia Soc. Intl. 5:6 (abstr.).

Hara, A.H. 1994. Ornamentals and flowers, p. 329-347. In: R.E. Paull and J.W. Amstrong (eds.). Insect pests and fresh horticultural products: Treatments and responses. CAB Intl., Wallingford, U.K.

Hara, A.H., J.D. Hansen, V.L. Tenbrink, and K.T. Sewake. 1991. Minimizing shipment rejections due to insect pests, p. 5353. In: Proceedings: The Hawaii Tropical Cut Flower Industry Conference. HITAHR, Univ. Hawaii Res. Ext. Serv. \#134.

Hara, A.H., T.Y. Hata, B.K.S. Hu, and V.L. Tenbrink. 1993. Hot water immersion as a potential quarantine treatment against Pseudaulacaspis cockerelli (Homoptera: Diaspididae). J. Econ. Entomol. 86:1167-1170.

Hara, A.H., T.Y. Hata, B.S. Hu, and M.M.C. Tsang. 1997. Hot air induced thermotolerance of red ginger flowers and mealybugs to postharvest hot water immersion. Postharvest Biol. Technol. 12:101-108.

Hara, A.H., T.Y. Hata, V.L. Tenbrink, B.K.S. Hu, and R.T. Kaneko. 1996. Postharvest heat treatment of red ginger flowers as a possible alternative to chemical insecticidal dip. Postharvest Biol. Technol. 7:137-144.

Hata, T.Y., A.H. Hara, B.K.S. Hu, and V.L. Tenbrink. 1994. A systems approach for quarantine security, p. 42-43. In: Proceedings: The Hawaii Tropical Cut Flower Industry Conference. Univ. Hawaii HITAHR 07.10.94.

Heliconia Society International. 1989. Warning: On air freight shipments of heliconia rhizomes. Bul. Heliconia Soc. Intl. 4:6.
Ka-ipo, R., W.S. Sakai, S.C. Furutani, and M. Collins. 1989. Effect of postharvest treatment with antitranspirants on the shelflife of Heliconia psittacorum cv. Parakeet cut flowers. Bul. Heliconia Soc. Intl. 4:1314

Kofranek, A.M. 1982. Postharvest handling methods for bird of paradise flowers, p. 41. In: Proceedings-5th Annual Ornamental Short Course. Univ. Hawaii at Manoa, Hawaii Inst. Trop. Agr. Human Resources Res. Ext. Ser. \#043.

Kronestedt, E.C., M. Greger, and A.W. Robards. 1989. The nectar of the Strelitzia reginae flower. Physiol. Plant. 77:341346

Kronestedt, E.C. and A.W. Robards. 1987. Sugar secretion from the nectary of Strelitzia: An ultrastructural and physiological study. Protoplasma 137:168-182.

Marousky, F.J. 1971. Inhibition of vascular blockage and increased moisture retention in cut roses induced by $\mathrm{pH}, 8$ hydroxyqinoline citrate, and sucrose. J. Amer. Soc. Hort. Sci. 96:38-41.

Nowak, J. and R.M. Rudnicki. 1990. Postharvest handling and storage of cut flowers, Florist greens and potted plant. Timber Press, Portland, Ore.

Paull, R.E. 1987. Effect of storage duration and temperature on cut anthurium flowers. HortScience 22:459-460.

Paull, R.E. 1991. Postharvest handling of Hawaii cut flowers for export, p. 40-48. In: Proceedings: The Hawaii Tropical Cut Flower Industry Conference. HITAHR, Univ. Hawaii Res. Ext. Serv. \#134.

Paull, R.E. and T. Chantrachit. 2001. Benzyladenine and the vase life of tropical ornamentals. Postharvest Biol. Technol. 21:303-310.

Powell, J. 1989. Care and handling of heliconia flowers. N. Territory Dept. Primary Ind. and Fisheries Tech. Bul.

Powell, J. 1991. Growing heliconias for cut flowers. N. Territory Dept. Primary Ind. Fisheries Agnote No. 442 (Feb):1-4.

Rietow, D. 1986. Packing and shipping of cut ginger. Hort. Dig. (Hawaii) 80:7-8.

Sacalis, J.N. 1993. Cut flowers: Prolonging freshness, Postproduction care and handling. $2^{\text {nd }}$ ed. Ball Publ., Batavia, Ill.

Tanouye, R. 1986. Grower panel on packing and shipping cut flowers. Hort. Dig. (Hawaii) 80:8.

Tenbrink, V.L., J.D. Hansen, and A.H. Hara. 1991a. Phytotoxicity of Safer insecticidal soap and mavrik aquaflow as a postharvest dip. Insecticide Acaricide Tests 16:61-262.
Tenbrink, V.L., J.D. Hansen, and A.H. Hara. 1991b. Phytotoxicity of mavrik aquaflow and safer insecticidal soap when used as a dip on cut flowers and foliage, $p$. 178-179. In: Proceedings: The Hawaii Tropical Cut Flower Industry Conference. HITAHR, Univ. Hawaii Res. Ext. Serv. \#134.

Tenbrink, V.L., A.H. Hara, B.K.S. Hu, and T.Y. Hata. 1994. Hot water as a postharvest treatment, p. 44-45. In: $\mathrm{Ha}^{-}$ waii Tropical Cutflower and Ornamental Plant Industry Conference. Univ. Hawaii. HITAHR 07.10.94.

Tjia, B. 1985. Longevity and postharvest studies of various Heliconia psittacorum bracts. Bul. Heliconia Soc. Intl. 1:6.

Tjia, B. 1988. Postharvest studies of the red plume ginger (Alpinia purpurata). Bul. Heliconia Soc. Intl. 3 (3):7-8.

Tjia, B. and T.K. Broschat. 1987. Harvest and postharvest handling of cut plume ginger. Univ. Fla. Ornamental Hort. Dept. News Sheet NS-ORH-87-6.

Tjia, B. and T.J. Sheehan. 1984. Preserving profits and beauty. Greenhouse Manager 2 (11):95-100.

United Nations Environmental Program. 1992. Montreal protocol assessment supplement. Methyl bromide. United Nations Environment Programme. US Govt. Printing Office, Wash., D.C.

van Doorn, W.G., K. Schurer, and Y.D. Witte. 1989. Role of endogenous bacteria in vascular blockage of cut rose flowers. J. Plant Physiol. 134:375-381.

Whittaker, J., T.A. Nell, J.E. Barrett, and T.J. Sheehan. 1992. Cytokinin dips and sucrose holding solutions increase the postharvest longevity of 'Nitta' anthurium and pink gingers. HortScience 181:489492.

Whittaker, J.M. 1993. Postharvest handling procedure for Jamaican grown cut flowers, MS thesis. Univ. Fla., Gainsville.

Yamakawa, R.M., T.T. Sekioka, F.R. Matsuno, R.E. Paull, C.A. Bobisud, and S.A. Ferreira. 1999. Three new cultivars of Heliconia orthotricha: 'Kauai Morning Sun', 'Kauai Christmas', and 'Kauai Sunset'. Univ. Hawaii College of Trop. Agr. Human Resources, New Plants for Hawaii NPH-4.

Yotpanya, P. 1995. Ruam Hit Mai Tad Dok Meung Ron (Tropical cut flowers). $1^{\text {st }}$ ed. Matichon, Bangkok, Thailand. 